\title{
Melatonin Treatment of Apricot Trees Leads to Maintenance of Fruit Quality Attributes during Storage at Chilling and Non-Chilling Temperatures
}

\author{
Jorge Medina-Santamarina ${ }^{1}$, Pedro Javier Zapata ${ }^{1}{ }^{\mathbb{D}}$, Juan Miguel Valverde ${ }^{1} \mathbb{C}$, Daniel Valero ${ }^{1} \mathbb{D}$, \\ María Serrano $^{2}$ (D) and Fabián Guillén ${ }^{1, *}$ (D) \\ 1 Department of Food Technology, EPSO, University Miguel Hernández, Ctra. Beniel km. 3.2, \\ 03312 Alicante, Spain; jorge.medina01@goumh.umh.es (J.M.-S.); pedrojzapata@umh.es (P.J.Z.); \\ jm.valverde@umh.es (J.M.V.); daniel.valero@umh.es (D.V.) \\ 2 Department of Applied Biology, EPSO, University Miguel Hernández, Ctra. Beniel km. 3.2, \\ 03312 Alicante, Spain; m.serrano@umh.es \\ * Correspondence: fabian.guillen@umh.es; Tel.: +34-96-6749756
}

\section{check for} updates

Citation: Medina-Santamarina, J.; Zapata, P.J.; Valverde, J.M.; Valero, D.; Serrano, M.; Guillén, F. Melatonin Treatment of Apricot Trees Leads to Maintenance of Fruit Quality Attributes during Storage at Chilling and Non-Chilling Temperatures. Agronomy 2021, 11, 917. https:// doi.org/10.3390/agronomy11050917

Academic Editor:

Antonios Chrysargyris

Received: 22 March 2021

Accepted: 4 May 2021

Published: 7 May 2021

Publisher's Note: MDPI stays neutral with regard to jurisdictional claims in published maps and institutional affiliations.

Copyright: (C) 2021 by the authors Licensee MDPI, Basel, Switzerland. This article is an open access article distributed under the terms and conditions of the Creative Commons Attribution (CC BY) license (https:// creativecommons.org/licenses/by/ $4.0 /)$.

\begin{abstract}
The effects of preharvest melatonin treatment on apricot crop yield and fruit quality properties at harvest and during storage have not yet been investigated. Apricot trees, of the 'Colorado' and 'Mikado' cultivars, were sprayed with $0.1 \mathrm{mM}$ melatonin at three key points of fruit development. Fruit were harvested at commercial ripening stage and yield was higher in melatonin treated trees than in the controls. Fruit were stored at 1 and $8{ }^{\circ} \mathrm{C}$ for 21 and 28 days, respectively. Samples were taken weekly and left at $20^{\circ} \mathrm{C}$ for 1 day. Weight losses, as well as reduction in firmness and acidity, were delayed in fruits from melatonin treated trees, showing an effect of treatment on delaying the postharvest ripening process, which was attributed to a reduced ethylene production in both cultivars and at both storage temperatures. In addition, chilling injury symptoms were observed in apricots stored at $1{ }^{\circ} \mathrm{C}$, which were reduced by preharvest melatonin treatment. Moreover, apricot from melatonin-treated fruit retained higher total phenolic content than the controls after 14 days of storage, although the phenolic profile was not affected by treatment. Thus, melatonin could be a useful tool for practical purposes to improve apricot crop yield and maintain fruit quality properties during storage.
\end{abstract}

Keywords: Prunus armeniaca; yield; firmness; acidity; soluble solids; phenolics

\section{Introduction}

Apricot (Prunus armeniaca L.) is a stone fruit highly appreciated by consumers due to its pleasant taste and flavor; nutritive properties; and its content of bioactive compounds with antioxidant activity, such as phenolics, vitamins, and carotenoids (Egea et al., 2007; Fan et al., 2018). Apricot is a climacteric fruit that is usually harvested at the pre-climacteric stage and undergoes a rapid ripening process during storage, leading to quality losses and deterioration in 3-4 weeks at cold storage, depending on cultivar and storage temperature, which are accelerated upon transference to ambient temperature [1-3]. Thus, storage at low temperature is not enough for apricot delivery to distant markets. In this sense, additional postharvest treatments, such as coating with aloe vera gel [4], storage at a controlled atmosphere [5], and 1-methylciclopropene [6] or polyamine treatments [1], among others, combined with cold storage, have been assayed to delay ripening and maintain fruit quality.

Melatonin was first identified in 1995 in mono and dicotyledonous plant families [7] and, nowadays, it is considered as a multifunctional plant growth regulator, having effects in a wide range of plant physiological processes, including alleviation of the oxidative damages caused by different biotic and abiotic stresses [8,9]. In addition, recent reports have shown a role of melatonin on fruit ripening, although most of them are focused on 
postharvest treatments [10]. Thus, $0.5 \mathrm{mM}$ melatonin dipping for $1 \mathrm{~h}$ delayed changes of ripening parameters in 'Guifei' mangoes through inhibition of ethylene and ABA biosynthesis [11]. Accordingly, $\mathrm{Hu}$ et al. [12] reported delayed ripening and ethylene inhibition in banana fruit after postharvest melatonin treatment, which was dose-dependent in the range of 0.05 to $0.5 \mathrm{mM}$. Similar results have been reported in nectarines and peaches $[13,14]$. However, the effects of melatonin preharvest treatment on fruit ripening on trees have been evaluated in a few papers, showing different effects depending on fruit species, concentration, or application time. Thus, melatonin 0.1 and $0.01 \mathrm{mM}$ applied at pit hardening inhibited ripening in sweet cherry fruits [15], while irrigation of tomato plants with $0.1 \mathrm{mM}$ melatonin increased sugar and lycopene concentration in fruits, showing a positive effect on fruit ripening [16]. In apricot, foliar spray melatonin treatment increased yield and fruit weight, although no effect on on-tree ripening was observed [17] (Abd El-Naby et al., 2019). However, to the best of our knowledge, no literature is available regarding the effect of preharvest melatonin treatment on fruit quality properties at harvest and during storage. Thus, the present experiment was aimed at evaluating the effects of preharvest melatonin treatment on the on-tree apricot ripening process as well as on the evolution of quality, nutritional, and functional properties during storage at 1 and $8{ }^{\circ} \mathrm{C}$ by using two cultivars, 'Colorado' and 'Mikado'.

\section{Materials and Methods}

\subsection{Plant Material and Experimental Design}

Experiments were performed in a commercial field plot located at Cieza (Murcia, Spain) with apricot trees (Prunus armeniaca L.) of cultivars 'Colorado' and 'Mikado'. Trees were treated with freshly prepared solutions of melatonin $0.1 \mathrm{mM}$ containing $1 \mathrm{~mL} \mathrm{~L}^{-1}$ Tween or distilled water with $1 \mathrm{~mL} \mathrm{~L}^{-1}$ Tween as the control. Three replicates of three trees were used for each treatment and cultivar. Treatments were applied by foliar spray of $3 \mathrm{~L}$ per tree by using a manual sprayer machine at pit hardening, final fruit growth, and 4 days before harvest. Fruit were harvested at commercial ripening, based on the characteristic skin color of each cultivar. Total production per tree was weighed and fruit counted to obtain data of yield per tree and fruit weight average. Then, a sample of ca $25 \mathrm{~kg}$ of each replicate was taken and transferred to the laboratory in $2 \mathrm{~h}$, and 10 lots of ten fruits, homogenous in size and color and without visual defects, were performed from each replicate and treatment, 5 of them being stored at $1{ }^{\circ} \mathrm{C}$ and the remaining 5 lots at $8{ }^{\circ} \mathrm{C}$ and $85 \% \mathrm{RH}$. After $0,7,14,21$, and 28 days of storage, one lot was taken at random for each replicate, treatment, and storage temperature and stored for 1 day at $20^{\circ} \mathrm{C}$ and $70 \%$ $\mathrm{RH}$, and then the following parameters were measured.

\subsection{Ethylene Production, Respiration Rate, and Quality Parameters}

The weight of each apricot lot was measured at day 0 and after each storage period, and weight loss was expressed as a percentage with respect to weight at day 0 . To quantify ethylene production and respiration rate, each fruit lot was hermetically sealed in a $3 \mathrm{~L}$ jar for $60 \mathrm{~min}$. After that, $4 \mathrm{~mL}$ from the holder atmosphere were withdrawn with a syringe. Two milliliters was used to quantify, in duplicate, ethylene by using a Hewlett-Packard ${ }^{\mathrm{TM}}$ $5890 \mathrm{~A}$ gas cromatograph, and the remaining $2 \mathrm{~mL}$ was used to quantify, in duplicate, $\mathrm{CO}_{2}$ by using a Shimadzu TM 14A gas chromatograph (Kyoto, Japan), equipped with a thermal conductivity detector. Chromatographic conditions have been previously described [11], and ethylene production and respiration rate were expressed as $\mathrm{nL} \mathrm{g}^{-1} \mathrm{~h}^{-1}$ and $\mathrm{mg}$ of $\mathrm{CO}_{2} \mathrm{~kg}^{-1} \mathrm{~h}^{-1}$, respectively.

Chilling injury damage was evaluated by five trained judges according to a scale from 0 to 5 . To measure fruit color, one image of each cheek side of the 10 fruits of each of the 3 replicates for each treatment were captured, saved as a JPEG file, and analyzed using the software ImageJ v1.52a (NIH Image, National Institutes of Health, Bethesda, MD, USA). The CIELab model was used to express color as $\mathrm{L}^{*}, \mathrm{a}^{*}$, and $\mathrm{b}^{*}$ parameters. Fruit firmness was measured using a TX-XT2i Texture Analyzer (Stable Mycrosystems, Godalming, UK) 
equipped with a flat probe that applied a force to achieve a 3\% deformation of the fruit diameter. Results were expressed as the relation between the applied force and the travelled distance $\left(\mathrm{N} \mathrm{mm}^{-1}\right)$ and are the mean $\pm \mathrm{SE}$. After that, fruit were peeled and the flesh cut into small pieces to obtain a homogeneous sample of each replicate. About $50 \mathrm{~g}$ were squeezed through two layers of cotton cloth, and the juice was used to measure total soluble solids (TSS) and titratable acidity (TA). TA was determined in duplicate in each sample by automatic titration (785 DMP Titrino, Metrohm) of $1 \mathrm{~mL}$ of juice diluted in $25 \mathrm{~mL}$ of distilled $\mathrm{H}_{2} \mathrm{O}$ with $0.1 \mathrm{~N} \mathrm{NaOH}$ up to $\mathrm{pH}$ 8.1, and results were expressed as g malic acid equivalent $100 \mathrm{~g}^{-1}$ on a fresh weight basis. TSS were also measured in duplicate in the juice of each sample using a digital refractometer (Atago PR-101, Atago Co. Ltd., Tokyo,

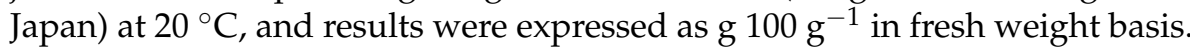

\subsection{Total and Individual Phenolic Quantification}

Total phenolis compounds were extracted by homogenizing $5 \mathrm{~g}$ of fruit pulp samples with $15 \mathrm{~mL}$ of water:methanol $(2: 8, v / v)$ containing $2 \mathrm{mM} \mathrm{NaF}$ using an Ultraturrax (T18 basic, IKA, Berlin, Germany) for $30 \mathrm{~s}$. The extracts were centrifuged at $10,000 \times g$ for $10 \mathrm{~min}$ at $4{ }^{\circ} \mathrm{C}$ and total phenolics were quantified in the supernatant, in duplicate, using the FolinCiocalteu reagent, as previously described [18]. Results were expressed as mg gallic acid equivalent (GAE) $\mathrm{g}^{-1}$ on a dry weight basis and are the mean \pm SE. To quantify individual phenolics, $1 \mathrm{~mL}$ of the above supernatant was filtered through a $0.45 \mu \mathrm{m}$ PVDF filter (Millex HV13, Millipore, Bedford, MA, USA) and used for HPLC analyses using an Agilent HPLC 1100 series machine equipped with a photodiode array detector (Agilent Technologies, Waldbronn, Germany). The HPLC was equipped with a C18 column (Mediterranea Sea 18, Teknokroma, Barcelona, Spain) of $25 \mathrm{~cm} \times 0.46 \mathrm{~cm}$ i.d. and $5 \mu \mathrm{m}$ particle size and a C18 security guard of $1 \mathrm{~cm} \times 0.32 \mathrm{~cm}$ i.d. (Ultraguard Sea 18, Teknokroma, Barcelona, Spain). Mobile phases A and B were water:formic acid $(99.9: 0.1, v / v)$ and acetonitrile, respectively,

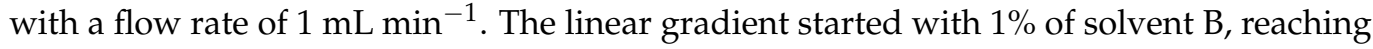
$30 \%$ of solvent B at $30 \mathrm{~min}, 50 \%$ at $40 \mathrm{~min}$, and $95 \%$ at $45 \mathrm{~min}$, which was maintained up to $50 \mathrm{~min}$ and then returned to initial conditions after $5 \mathrm{~min}$. The injection volume was $20 \mu \mathrm{L}$ and the temperature of column was $30^{\circ} \mathrm{C}$. Chromatograms were recorded at $320 \mathrm{~nm}$, and neochlorogenic acid, chlorogenic acid, and rutin were quantified by comparison with calibration curves performed with authentic standards purchased from Sigma-Aldrich (Darmstadt, Germany).

\subsection{Statistical Analysis}

The experiments were performed over two years (2019 and 2020) and in both years, a factorial design with melatonin treatments $(0$ and $0.1 \mathrm{mM})$ and storage time $(0,7,14,21$, and 28 days) with three triplicates $(n=3)$ of three trees per replicate for melatonin treatment and of three lots of ten fruit for each sampling date during storage was performed. For all the measured parameters, data are the mean $\pm S E(n=6)$ of the results from both years. An analysis of variance (ANOVA) was performed using the SPSS software version 20 (SPSS Inc., Chicago, IL, USA) and means were compared by Tukey's test. Differences at $p<0.05$ were considered significant. Least Significance Differences (LSD), at $5 \%$ level of probability, were calculated when significant differences among treatments were detected. In addition, a $t$-test was performed by comparison between the control and the melatonin treated fruit for each cultivar, storage temperature, and sampling date.

\section{Results}

\subsection{Fruit Weight and Crop Yield}

Apricot fruit were harvest when fruit reached their commercial ripening stage, based on color of fruit surface, so that two harvestings were performed for both cultivars in the control or in the treated trees. Melatonin tree treatment led to a significant increase $(p<0.05)$ of fruit weight, ca. 8.5 and 9.2\% in 'Colorado' and 'Mikado' cultivars, respectively, although no significant effect was observed on the number of fruit harvested per tree. Thus, 
yield, expressed as $\mathrm{kg}$ harvested per tree was significantly higher $(p<0.05)$ in melatonin treated trees than in the controls (Table 1).

Table 1. Tree yield (kg), fruit weight (FW, g) at harvest, and color parameters at harvest and after 21 days of storage at 1 or $8{ }^{\circ} \mathrm{C}$ in 'Colorado' and 'Mikado' apricots from the control and melatonin $0.1 \mathrm{mM}$ treated trees.

\begin{tabular}{cccccc}
\hline & & \multicolumn{2}{c}{ 'Colorado' } & \multicolumn{2}{c}{ 'Mikado' $^{\prime}$} \\
\cline { 2 - 6 } & Days & Control & Melatonin & Control & Melatonin \\
\hline Yield & & $26.25 \pm 0.71 \mathrm{a}$ & $28.35 \pm 0.75 \mathrm{~b}$ & $19.65 \pm 0.85 \mathrm{a}$ & $21.42 \pm 0.83 \mathrm{~b}$ \\
FW & 0 & $54.77 \pm 1.75 \mathrm{a}$ & $59.46 \pm 1.08 \mathrm{~b}$ & $59.84 \pm 1.11 \mathrm{a}$ & $67.38 \pm 1.54 \mathrm{~b}$ \\
Colour a* & 0 & $36.35 \pm 0.99 \mathrm{aA}$ & $37.22 \pm 0.48 \mathrm{aA}$ & $27.53 \pm 1.02 \mathrm{aA}$ & $26.24 \pm 1.08 \mathrm{aA}$ \\
& 21 at $1{ }^{\circ} \mathrm{C}$ & $40.73 \pm 1.34 \mathrm{aB}$ & $42.81 \pm 0.60 \mathrm{aB}$ & $34.74 \pm 1.06 \mathrm{aB}$ & $34.62 \pm 0.59 \mathrm{aB}$ \\
& 21 at $8{ }^{\circ} \mathrm{C}$ & $44.84 \pm 0.49 \mathrm{aC}$ & $45.35 \pm 0.41 \mathrm{aC}$ & $36.4 \pm 1.12 \mathrm{aB}$ & $35.68 \pm 0.93 \mathrm{aB}$ \\
Colour b $^{*}$ & 0 & $61.01 \pm 1.10 \mathrm{aB}$ & $60.72 \pm 0.56 \mathrm{aA}$ & $61.91 \pm 1.27 \mathrm{aA}$ & $64.32 \pm 1.38 \mathrm{aB}$ \\
& 21 at $1{ }^{\circ} \mathrm{C}$ & $62.8 \pm 0.72 \mathrm{aB}$ & $62.37 \pm 0.40 \mathrm{aA}$ & $62.97 \pm 1.22 \mathrm{aA}$ & $59.01 \pm 1.02 \mathrm{aA}$ \\
& 21 at $8{ }^{\circ} \mathrm{C}$ & $58.95 \pm 0.60 \mathrm{aA}$ & $60.06 \pm 1.03 \mathrm{aA}$ & $59.52 \pm 1.79 \mathrm{aA}$ & $61.68 \pm 1.45 \mathrm{aA}$ \\
${\text { Colour } \mathrm{L}^{*}}^{0}$ & $61.02 \pm 1.01 \mathrm{aC}$ & $60.46 \pm 0.63 \mathrm{aC}$ & $61.71 \pm 0.98 \mathrm{aC}$ & $63.61 \pm 1.14 \mathrm{aB}$ \\
& 21 at $1{ }^{\circ} \mathrm{C}$ & $58.84 \pm 0.58 \mathrm{aB}$ & $58.18 \pm 0.49 \mathrm{aB}$ & $58.69 \pm 1.09 \mathrm{aB}$ & $54.77 \pm 1.06 \mathrm{aA}$ \\
& 21 at $8{ }^{\circ} \mathrm{C}$ & $52.71 \pm 0.55 \mathrm{aA}$ & $53.88 \pm 0.97 \mathrm{aA}$ & $53.95 \pm 1.56 \mathrm{aA}$ & $56.09 \pm 1.35 \mathrm{aA}$ \\
\hline
\end{tabular}

Data are the mean \pm SE of fruits harvested from three replicates of three trees for 2019 and 2020 experiments. For each cultivar and sampling date, different lowercase letters show significant differences $(p<0.05)$ between the control and the melatonin treatments $(t$-test). For each cultivar and treatment, different uppercase letters show significant differences $(p<0.05)$ during storage.

\subsection{Weight Loss, Ethylene Production and Respiration Rate}

Weight loss increased during storage in both apricot cultivar and both storage temperatures, reaching final values of $29.65 \pm 2.07$ and $26.62 \pm 1.00 \%$ in 'Colorado' control fruits after 21 and 28 days of storage at 8 and $1{ }^{\circ} \mathrm{C}$, respectively (Figure $1 \mathrm{~A}$ ) and $29.43 \pm 0.72$ and $21.98 \pm 2.30$ and in 'Mikado', respectively (Figure 1B). However, weight losses were significantly lower $(p<0.05)$ in fruits from melatonin treated trees, with reductions of 36 and 25\% in 'Colorado' and 19 and $13 \%$ in 'Mikado', taking into account the data of all sampling dates during storage at 1 and $8{ }^{\circ} \mathrm{C}$, respectively (Figure 1A,B). Ethylene production rate increased sharply from harvest day to day $7+1$ in the control fruit, reaching maxima values of $33.77 \pm 1.128$ and $43.59 \pm 1.34 \mathrm{~nL} \mathrm{~g}^{-1} \mathrm{~h}^{-1}$ in the 'Colorado' and 'Mikado' control fruits stored at $8{ }^{\circ} \mathrm{C}$, respectively, and were significantly lower, $(p<0.05) 12.42 \pm 3.33$ and $18.53 \pm 1.41 \mathrm{~nL} \mathrm{~g}^{-1} \mathrm{~h}^{-1}$, respectively, in those stored at $1{ }^{\circ} \mathrm{C}$. After that, ethylene production deceased in the fruits of both cultivars and storage temperatures (Figure 2A,B). Ethylene production in fruits from treated trees followed a similar pattern, although values were significantly lower than in the controls in all sampling dates for both cultivars and storage temperatures (Figure 2). Respiration rate increased steadily in both cultivars during storage at $8{ }^{\circ} \mathrm{C}$, with values significantly lower $(p<0.05)$ in fruits from treated trees than in the controls (Figure 3). Respiration rate of fruit stored at $1{ }^{\circ} \mathrm{C}$ was also significantly reduced $(p<0.05)$ in treated fruits with respect to the controls in both cultivars, although stabilization and decrease trends were observed after 14-21 days of storage. 


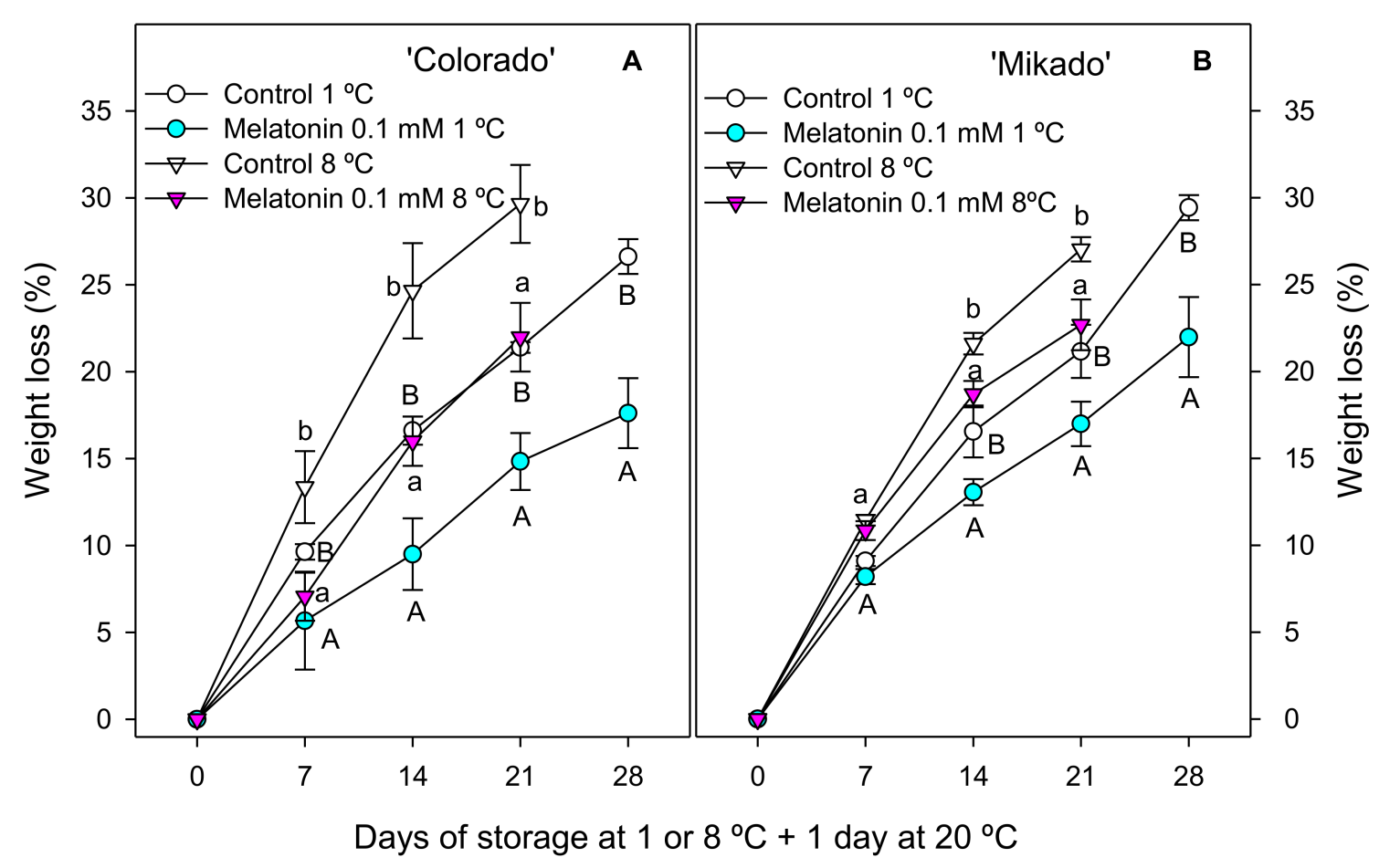

Figure 1. Weight loss of 'Colorado' (A) and 'Mikado' (B) apricots from the control and melatonin treated trees during storage at 1 and $8{ }^{\circ} \mathrm{C}$. Data are the mean $\pm \mathrm{SE}$ of three replicates of ten fruits from 2019 and 2020 experiments. LSD values were 1.196 and 0.943 for $(\mathbf{A}, \mathbf{B})$, respectively. Different capital and lowercase letters show significant differences $(t$-test, $p<0.05$ ) between treatments for each sampling date during storage at 1 and $8{ }^{\circ} \mathrm{C}$, respectively.

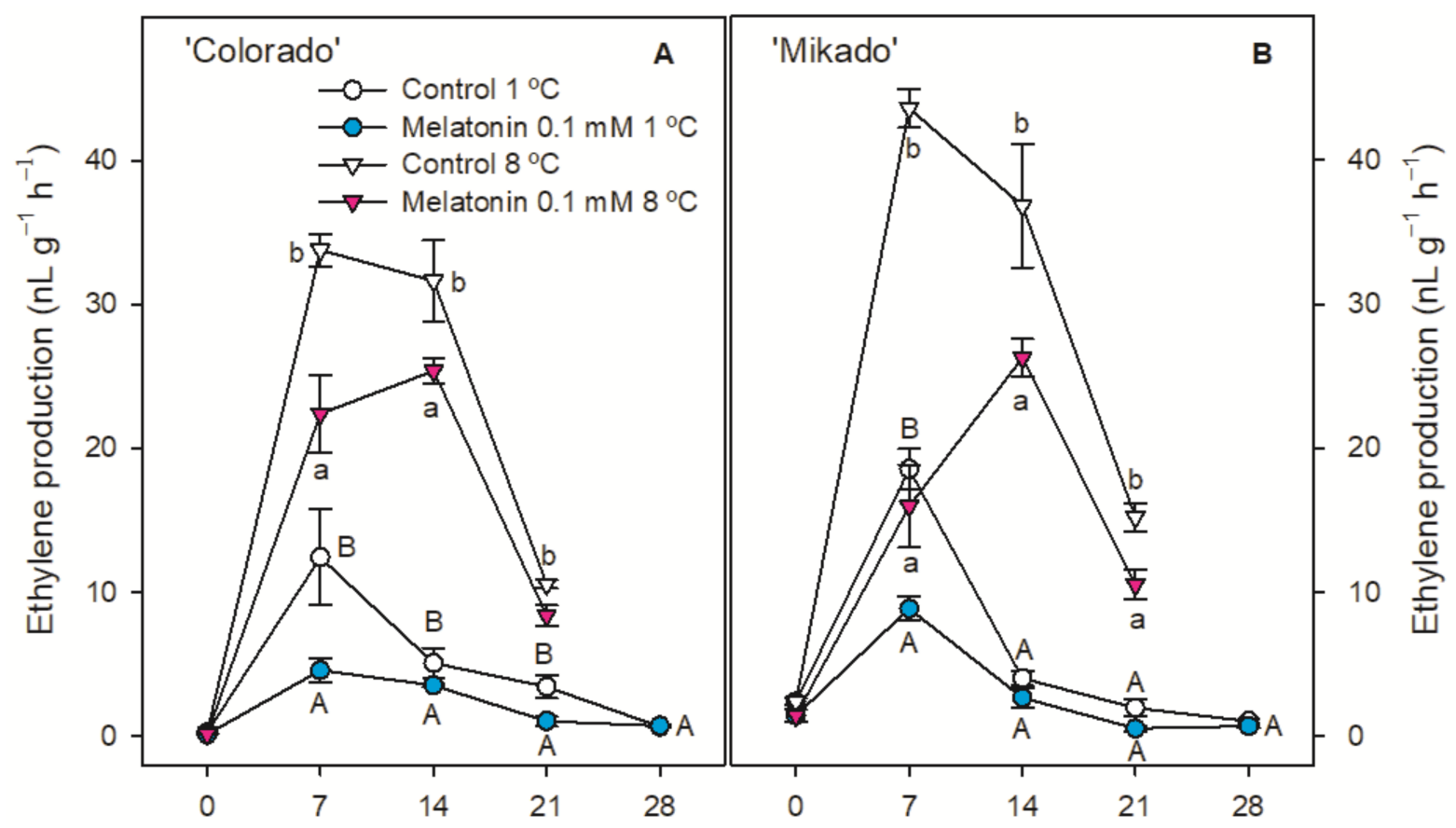

Days of storage at 1 or $8^{\circ} \mathrm{C}+1$ day at $20^{\circ} \mathrm{C}$

Figure 2. Ethylene production rate of 'Colorado' (A) and 'Mikado' (B) apricots from the control and melatonin treated trees during storage at 1 and $8{ }^{\circ} \mathrm{C}$. Data are the mean $\pm \mathrm{SE}$ of three replicates of ten fruits from 2019 and 2020 experiments. LSD values were 0.90 and 1.14 for (A,B), respectively. Different capital and lowercase letters show significant differences $(t$-test, $p<0.05)$ between treatments for each sampling date during storage at 1 and $8{ }^{\circ} \mathrm{C}$, respectively. 


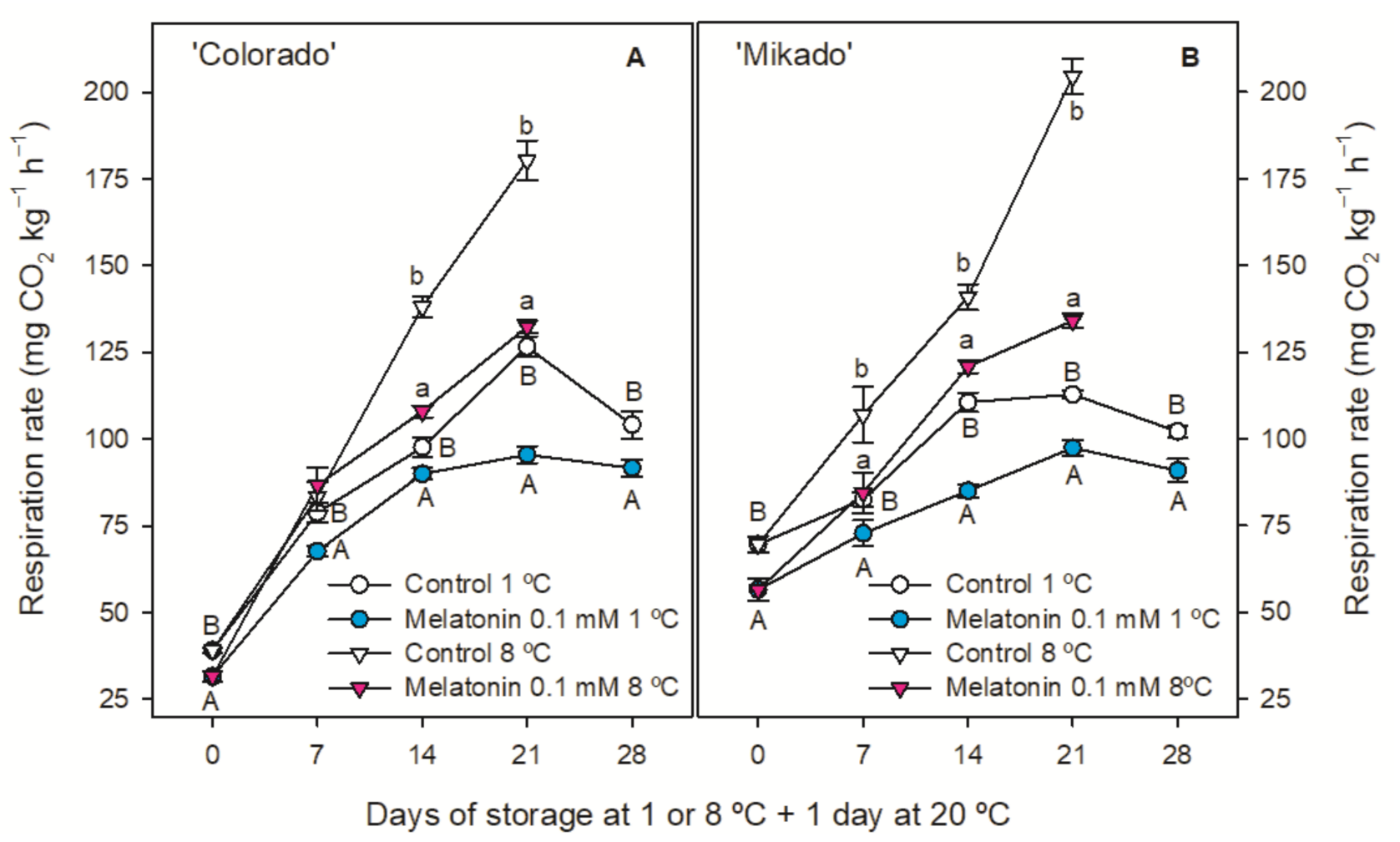

Figure 3. Respiration rate of 'Colorado' (A) and 'Mikado' (B) apricots from the control and melatonin treated trees during storage at 1 and $8{ }^{\circ} \mathrm{C}$. Data are the mean \pm SE of three replicates of ten fruits from 2019 and 2020 experiments. LSD values were 2.32 and 2.73 for $(\mathbf{A}, \mathbf{B})$, respectively. Different capital and lowercase letters show significant differences $(t$-test, $p<0.05)$ between treatments for each sampling date during storage at 1 and $8{ }^{\circ} \mathrm{C}$, respectively.

\subsection{Quality Parameters}

Fruit firmness at harvest was significantly higher $(p<0.05)$ in fruits from treated trees than in the controls, $16.50 \pm 0.53$ and $14.69 \pm 0.56 \mathrm{~N} \mathrm{~mm}^{-1}$, respectively, for 'Colorado' (Figure 4A) and $12.33 \pm 0.75$ and $9.74 \pm 0.52 \mathrm{~N} \mathrm{~mm}^{-1}$, respectively, for 'Mikado' (Figure 4B). A sharp decrease in fruit firmness was observed from day 0 to day $7+1$ of storage for both cultivars and storage temperatures, the rate of softening being lower thereafter. Fruit firmness was maintained at significantly higher values in melatonin treated fruits than in controls at $7+1$ and $14+1$ days of storage at $1{ }^{\circ} \mathrm{C}$ and at $7+1$ days in storage at $8^{\circ} \mathrm{C}$ (Figure 4), showing that the effect of preharvest melatonin treatment on reducing fruit softening was higher in fruits stored at lower temperature. Color parameters $\left(\mathrm{L}^{*}, \mathrm{a}^{*}\right.$ and $\left.\mathrm{b}^{*}\right)$ of apricot fruit at harvest were not affected by melatonin treatment, and their evolution during storage was similar in apricots from the control and treated fruits, although it was higher at 8 than at $1^{\circ} \mathrm{C}$ (Table 1$)$.

TSS and TA were similar $(p>0.05)$ in fruits from the control and treated trees, with

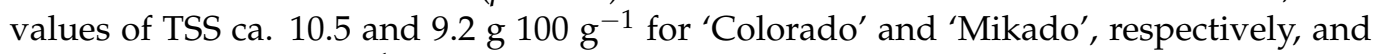

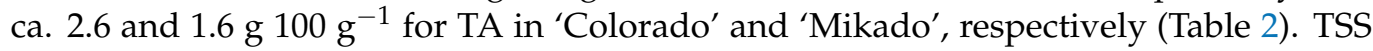
increased during storage at 1 and $8{ }^{\circ} \mathrm{C}$ in the control and treated fruits for both cultivars, although these increases were significantly lower $(p<0.05)$ in fruits from melatonin treated trees than in the controls from most sampling dates (Table 2). However, taking into account the great fruit weight losses that occurred during storage, the increase in TSS could be due to sugar concentration in fruit tissues. In fact, when TSS were calculated on a dry weight basis, no significant changes $(p>0.05)$ were observed during the whole storage time, with values in the range of $0.69-0.76$ and $0.55-0.65 \mathrm{~g} \mathrm{~g}^{-1}$ dry weight for 'Colorado' and 'Mikado', respectively (Figure S1). On the contrary, TA values, expressed on a fresh weight basis, decreased steadily during storage at $8{ }^{\circ} \mathrm{C}$ in 'Mikado', while decreases were only observed from day $21+1$ to day $28+1$ during storage at $1{ }^{\circ} \mathrm{C}$, and no significant 
changes $(p>0.05)$ were observed in 'Mikado' fruits during storage at 1 or $8^{\circ} \mathrm{C}$ (Table 2). Nevertheless, when TA was expressed on a dry weight basis, decreases were observed during the whole storage time, although values were significantly higher $(p<0.05)$ for apricots from melatonin treated trees than in the controls (Figure S2). Thus, TA values were increased by 18 and $15 \%$ in 'Colorado' and 13 and $11 \%$ in 'Mickado' fruits from melatonin treated trees stored at 1 and $8{ }^{\circ} \mathrm{C}$, respectively, with respect to the control fruits (Figure S2).

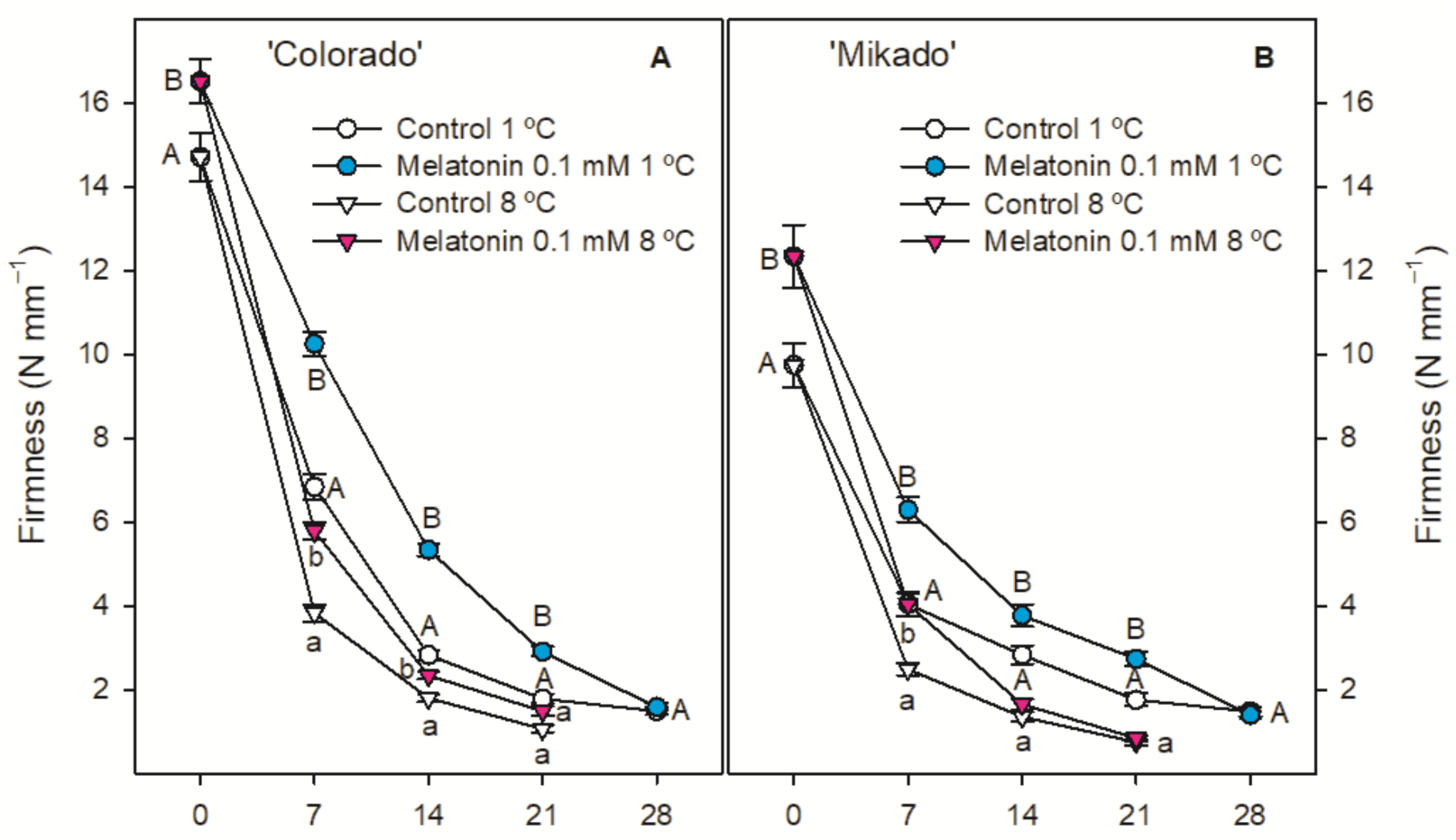

Days of storage at 1 or $8^{\circ} \mathrm{C}+1$ day at $20^{\circ} \mathrm{C}$

Figure 4. Fruit firmness of 'Colorado' (A) and 'Mikado' (B) apricots from the control and melatonin treated trees during storage at 1 and $8{ }^{\circ} \mathrm{C}$. Data are the mean \pm SE of three replicates of ten fruits from 2019 and 2020 experiments. LSD values were 0.23 and 0.37 for $(\mathbf{A}, \mathbf{B})$, respectively. Different capital and lowercase letters show significant differences $(t$-test, $p<0.05)$ between treatments for each sampling date during storage at 1 and $8^{\circ} \mathrm{C}$, respectively.

Table 2. Total soluble solids (TSS, $\mathrm{g} 100 \mathrm{~g}^{-1}$ fresh weight) and titratable acidity (TA, $\mathrm{g} 100 \mathrm{~g}^{-1}$ ) at harvest and after storage at 1 or $8{ }^{\circ} \mathrm{C}$ for 21 days +1 day at $20^{\circ} \mathrm{C}$ in 'Colorado' and 'Mikado' apricots from the control and melatonin $0.1 \mathrm{mM}$ treated trees.

\begin{tabular}{|c|c|c|c|c|c|}
\hline & & \multicolumn{2}{|c|}{ 'Colorado' } & \multicolumn{2}{|c|}{ 'Mikado' } \\
\hline & & Control & Melatonin & Control & Melatonin \\
\hline \multirow{3}{*}{ TSS } & Day 0 & $10.88 \pm 0.21 \mathrm{aA}$ & $10.25 \pm 0.31 \mathrm{aA}$ & $9.02 \pm 0.25 \mathrm{aA}$ & $9.23 \pm 0.08 \mathrm{aA}$ \\
\hline & $21 \mathrm{~d} 1{ }^{\circ} \mathrm{C}+1 \mathrm{~d} 20^{\circ} \mathrm{C}$ & $13.88 \pm 0.26 \mathrm{aB}$ & $12.60 \pm 0.15 \mathrm{bB}$ & $10.15 \pm 0.14 \mathrm{aB}$ & $9.92 \pm 0.12 \mathrm{bB}$ \\
\hline & $21 \mathrm{~d} 8{ }^{\circ} \mathrm{C}+1 \mathrm{~d} 20^{\circ} \mathrm{C}$ & $14.53 \pm 0.19 \mathrm{aC}$ & $13.30 \pm 0.26 \mathrm{bC}$ & $11.47 \pm 0.18 \mathrm{aC}$ & $10.55 \pm 0.04 \mathrm{bC}$ \\
\hline \multirow{3}{*}{ TA } & Day 0 & $2.55 \pm 0.03 \mathrm{aC}$ & $2.66 \pm 0.04 \mathrm{aB}$ & $1.83 \pm 0.05 \mathrm{aC}$ & $1.78 \pm 0.07 \mathrm{aB}$ \\
\hline & $21 \mathrm{~d} 1{ }^{\circ} \mathrm{C}+1 \mathrm{~d} 20^{\circ} \mathrm{C}$ & $2.32 \pm 0.04 \mathrm{aB}$ & $2.69 \pm 0.06 \mathrm{bB}$ & $1.65 \pm 0.04 \mathrm{aB}$ & $1.82 \pm 0.06 \mathrm{bB}$ \\
\hline & $21 \mathrm{~d} 8{ }^{\circ} \mathrm{C}+1 \mathrm{~d} 20^{\circ} \mathrm{C}$ & $1.70 \pm 0.06 \mathrm{aA}$ & $2.13 \pm 0.02 \mathrm{bA}$ & $1.32 \pm 0.11 \mathrm{aA}$ & $1.68 \pm 0.05 \mathrm{bA}$ \\
\hline
\end{tabular}

Data are the mean \pm SE of three replicates from 2019 and 2020 experiments. For each cultivar, different lowercase letters show significant differences $(p<0.05)$ between the control and the melatonin treatments $(t$-test), and different uppercase letters show significant differences $(p<0.05)$ during storage.

On the other hand, apricot stored at $1{ }^{\circ} \mathrm{C}$ manifested chilling injury symptoms, such as brown spot on the fruit surface, which increased, as did storage time. However, scores for chilling injury were significantly lower $(p<0.05)$ in fruit from melatonin treated trees 
than in the controls, for both cultivars, with reductions of 23 and $42 \%$ in 'Colorado' and 'Mikado', respectively, after 21 days of cold storage +1 day at $20^{\circ} \mathrm{C}$ (Table 3 ).

Table 3. Chilling injury scores for the control and melatonin treated fruit after 21 days of storage at $1{ }^{\circ} \mathrm{C}+1$ day at $20^{\circ} \mathrm{C}$. Chilling injury damage was rated according to a $0-5$ scale, as shown in the photograph on the last row.

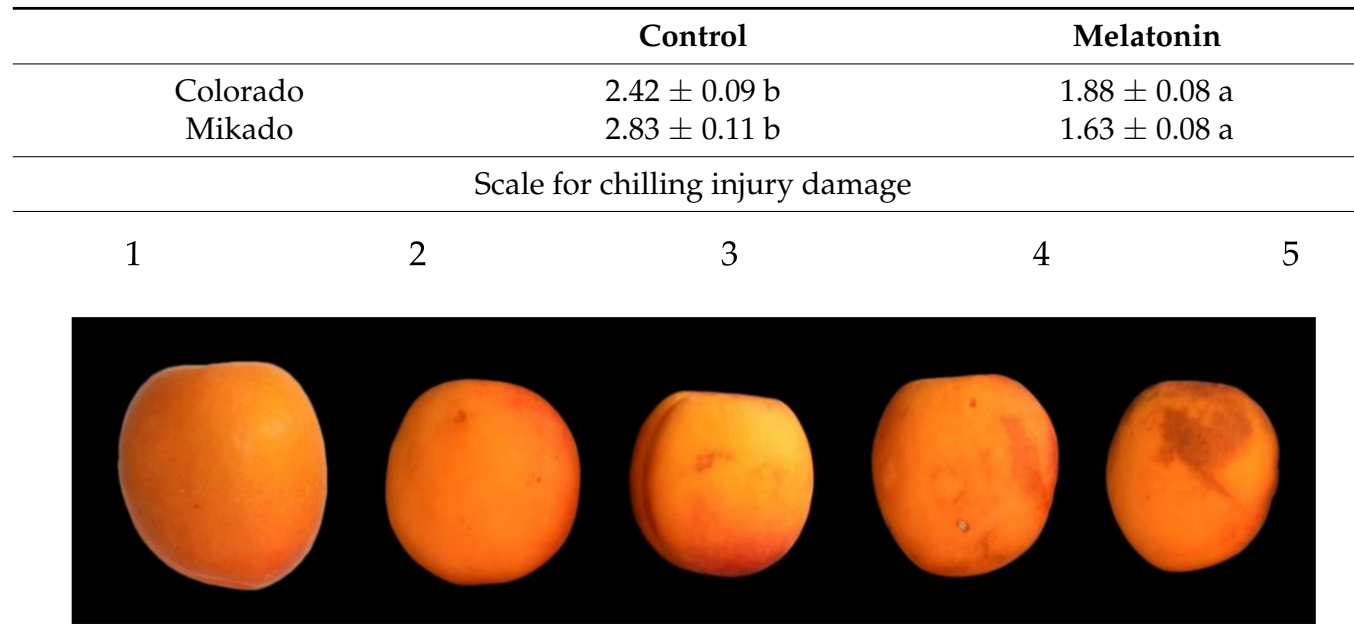

Data are the mean \pm SE of three replicates from 2019 and 2020 experiments. Different letters show significant differences $(p<0.05)$ between the control and treated fruit $(t$-test) for each cultivar.

\subsection{Individual and Total Phenolic Content}

Individual phenolics were quantified in both apricot cultivars from the control and the melatonin treated fruits at harvest, and similar phenolic profiles and concentrations were obtained without significant differences $(p>0.05)$ being attributed to melatonin treatment (Table 4). The major phenolic was chlorogenic acid, with values ca. 15 and $12.5 \mathrm{mg} 100 \mathrm{~g}^{-1}$ FW in 'Colorado' and 'Micado', respectively, followed by neochlorogenic acid and rutin (quercetin-3-O-rutinoside) at lower concentrations; 2-3 and 0.1-0.2 $\mathrm{mg} 100 \mathrm{~g}^{-1} \mathrm{FW}$, respectively. Total phenolic content at harvest (measured by the Folin-Ciocalteu reagent) was similar $(p>0.05)$ in fruits from the control and melatonin treated trees in both cultivars. During storage, total phenolic content, expressed on a dry weight basis, firstly increased and then decreased after $7+1$ days of storage in the control fruits at both temperatures, except in 'Mikado' apricots stored at $8{ }^{\circ} \mathrm{C}$, in which decreases were found from day 0 . Fruits from melatonin-treated trees followed a similar trend, although decreases were significantly delayed $(p<0.05)$ with respect to control fruits, occurring after $14+1$ and $21+1$ days in fruits stored at $8{ }^{\circ} \mathrm{C}$ and $1{ }^{\circ} \mathrm{C}$, respectively, in both cultivars (Figure $5 \mathrm{~A}, \mathrm{~B}$ ).

Table 4. Concentration of individual phenolics (mg $100 \mathrm{~g}^{-1} \mathrm{FW}$ ) at harvest in pulp of 'Colorado' and 'Mikado' apricots from the control and melatonin $0.1 \mathrm{mM}$ treated trees.

\begin{tabular}{ccccc}
\hline & \multicolumn{2}{c}{ 'Colorado' } & \multicolumn{2}{c}{ 'Mikado' } \\
\cline { 2 - 5 } & Control & Melatonin & Control & Melatonin \\
\hline Neochlorogenic acid & $3.60 \pm 0.28 \mathrm{a}$ & $2.52 \pm 0.16 \mathrm{a}$ & $2.10 \pm 0.06 \mathrm{a}$ & $2.16 \pm 0.18 \mathrm{a}$ \\
Chlorogenic acid & $15.78 \pm 1.08 \mathrm{a}$ & $14.73 \pm 0.46 \mathrm{a}$ & $12.25 \pm 0.21 \mathrm{a}$ & $12.61 \pm 0.60 \mathrm{a}$ \\
Rutin & $0.22 \pm 0.01 \mathrm{a}$ & $0.21 \pm 0.03 \mathrm{a}$ & $0.08 \pm 0.01 \mathrm{a}$ & $0.12 \pm 0.01 \mathrm{a}$ \\
\hline
\end{tabular}

Data are the mean \pm SE of three replicates of five fruits for 2019 and 2020 experiments. For each cultivar, different letters show significant differences $(p<0.05)$ between the control and melatonin treatments $(t$-test). 


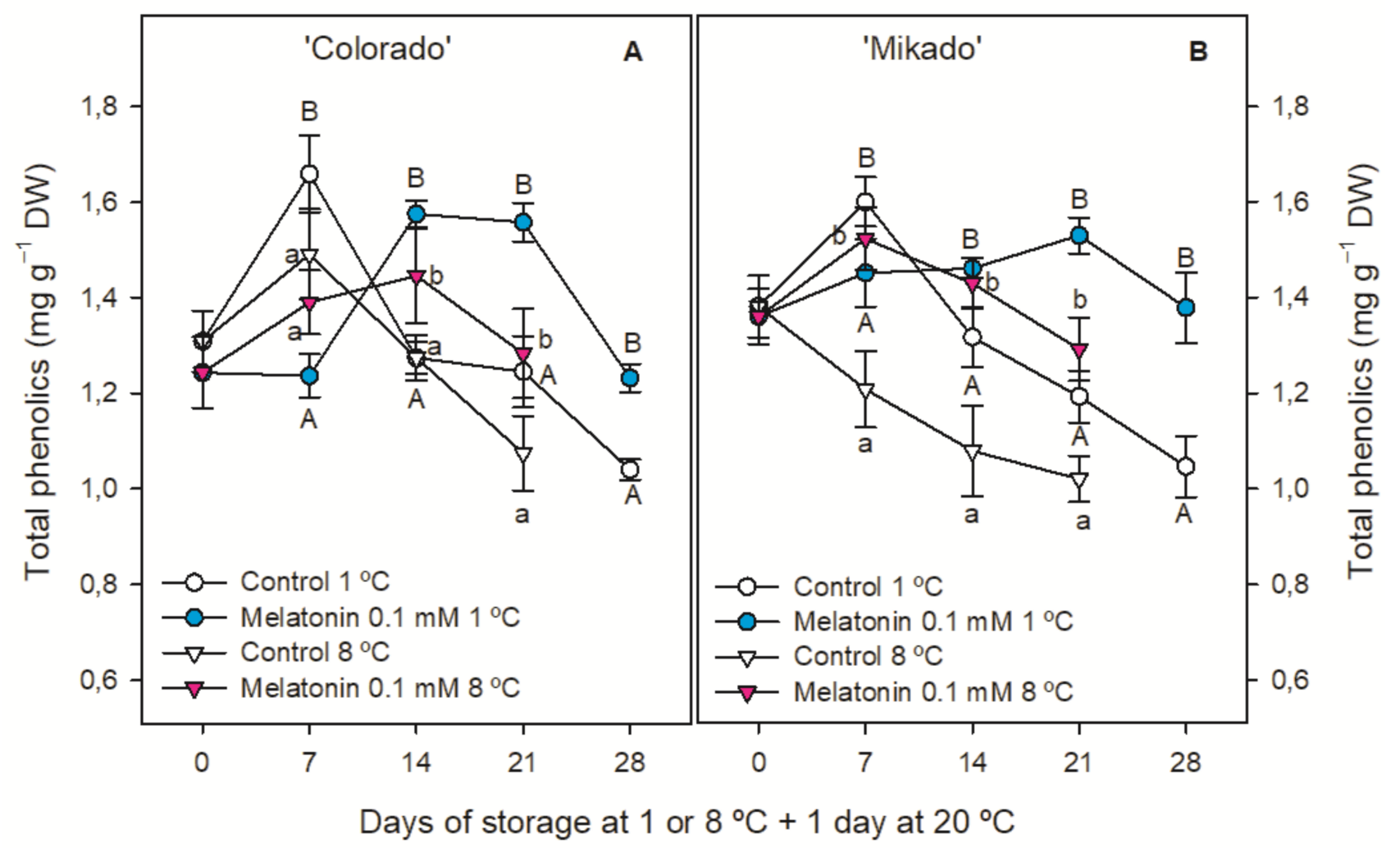

Figure 5. Total phenolic content on the flesh of 'Colorado' (A) and 'Mikado' (B) apricots from the control and melatonin treated trees during storage at 1 and $8{ }^{\circ} \mathrm{C}$. Data are the mean \pm SE of three replicates of ten fruits from 2019 and 2020 experiments. LSD values were 0.09 and 0.07 for $(\mathbf{A}, \mathbf{B})$, respectively. Different capital and lowercase letters show significant differences $(t$-test, $p<0.05)$ between treatments for each sampling date during storage at 1 and $8{ }^{\circ} \mathrm{C}$, respectively.

\section{Discussion}

Previously published papers have shown that foliar melatonin treatment affects crop yield. Thus, preharvest melatonin treatment of tomato plants ameliorated the reduction in yield occurring when plants were grown under rain acid stress conditions, although no increases were found in the control plants [19]. These results were attributed to the effects of melatonin treatment on boosting the stress tolerance of tomato plants to stress. In addition, a 37\% increase in the yield of tomato plants under water deficit stress was observed as a consequence of melatonin treatment at 30 and 50 days after transplanting, although increases of $14 \%$ were also observed in well-irrigated plans [20]. Moreover, seed soaking with melatonin or melatonin applied in the irrigation system also increased tomato plant yield [16]. These effects were attributed to an increase in leaf chlorophyll content and photosynthetic rate. Results of the present experiment also show an effect of melatonin spraying of apricot trees on increasing yield in both cultivars due to enhanced fruit weight (Table 1), leading to improving the economical profit of this crop. Accordingly, melatonin foliar spray treatment increased fruit weight and yield on the 'Canino' apricot as well as total chlorophyll and leaf area [17].

Weight loss, softening, and TA decreases are the major changes leading to apricot quality losses during storage $[4,6,21]$, which were delayed by preharvest melatonin treatments in both cultivars and storage temperatures. No previous reports are available in the literature regarding the effect of preharvest melatonin treatment on the evolution of fruit quality parameters during storage, although information exits concerning postharvest treatments. Weight loss is mainly due to transpiration rate through the fruit surface. The reduction observed in weight loss of fruits from melatonin treated trees with respect to those of the controls (Figure 1) might be attributed to an effect of melatonin increasing cuticle thickness, as recently proposed for nectarines [14] and mangos [22] after posthar- 
vest melatonin treatment. Fruit firmness sharply declined during storage in both apricot cultivars, being higher at 8 than at $1{ }^{\circ} \mathrm{C}$ (Figure 4), which has been attributed to increases on polygalacturonase, $\beta$-galactosidase, and pectin methyl esterase activities, leading to dissolution of the middle lamella, although degradation of cellulose also occurred due to cellulase activity [23]. However, fruit firmness at harvest was higher in fruit from melatonin treated tress than in the controls, and firmness losses were significantly $(p<0.05)$ delayed by preharvest melatonin treatment until $14 \mathrm{~d}$ of storage, this effect being higher at 1 than at $8{ }^{\circ} \mathrm{C}$ (Figure 4). Softening during storage was also delayed by postharvest melatonin treatment in nectarine [14], peach [13], pear [24], and mango [11] due to down-regulation of the expression of cell wall degrading enzymes. TSS and TA content in apricots are key factors affecting fruit taste and consumers' acceptance, as has been reported for other stone fruits $[2,3,25]$, and their maintenance during storage is a pivotal task. In 'Colorado' and 'Mikado' apricots, TSS increased and TA decreased throughout storage, these changes being higher at 8 than at $1{ }^{\circ} \mathrm{C}$ and significantly delayed in melatonin treated fruits (Table 2). However, fruit color parameters at harvest were not affected by melatonin treatment as expected because the main harvest criterion was fruit color. During storage, they evolved in a similar way to fruit from the control and treated trees, and no effects of preharvest melatonin treatment were observed, neither in the 'Colorado' nor in the 'Mikado' cultivars.

The effects of preharvest melatonin treatments on the evolution of quality parameters during storage show that the postharvest ripening process was delayed in apricots from melatonin treated trees at both storage temperatures, which could be attributed to their reduced ethylene production as compared with those of the control fruits (Figure 2). No previous reports are available in the literature regarding the effects of preharvest melatonin treatments on ethylene production of climacteric fruits during storage, although some information exists concerning postharvest treatments. Thus, $0.1 \mathrm{mM}$ melatonin applied after 1 month of cold storage to three pear cultivars ('Starkrimson', 'Abbé Fetel', and 'Red Anjou') decreased ethylene production during storage at $20^{\circ} \mathrm{C}$ due to a reduced expression of PCACS and PCACO genes, codifying for ACC-synthase and ACC-oxidase, respectively [26]. Accordingly, postharvest $0.1 \mathrm{mM}$ melatonin treatment reduced ethylene production on apple fruit during cold storage, due to the decreased expressions of $M d A C O 1$, MdACS1, MdAP2.4, and MdERF109 [27]. Lower ethylene production and expression of MaACO1 and MaACS1 genes were also observed in banana fruit during storage at ambient temperature as a consequence of postharvest melatonin treatment [12]. On the other hand, melatonin preharvest treatments reduced fruit respiration rate during storage at both temperatures (Figure 3), showing a reduction in fruit metabolism. Accordingly, postharvest $0.1 \mathrm{mM}$ melatonin treatment delayed and reduced the climacteric respiration peak during storage at different temperatures in other climacteric fruits such as peach [28], nectarines [14], pear [24], and mango [11], and even in non-climacteric fruits such as sweet cherry [29], leading to delay the postharvest ripening process.

Phenolic compounds are a wide range of secondary metabolites with beneficial effects on human health because their antioxidant properties have preventive effects on a wide range of chronic and age-related diseases such as hypertension; obesity; diabetes; and cardiovascular, neurodegenerative, and oncologic diseases [30-32]. Apricot phenolic profile and concentration are influenced by several factors, including cultivar, ripening stage, and agronomic and environmental conditions, as well as the part of fruit analyzed, with fruit peel containing relatively higher concentrations than fruit flesh [33-35]. For instance, total phenolic content ranged from 44 to $345 \mathrm{mg} 100 \mathrm{~g}^{-1}$ in five orange-fleshed apricot

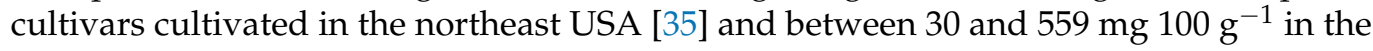
study performed by Drogoudi et al. [34] with 29 Greek and American apricot cultivars and using similar methods of analyses. Apricot cultivars of the present research had a total phenolic concentration at harvest of ca. $20 \mathrm{mg} 100 \mathrm{~g}^{-1}$ of fresh weight, showing that phenolic content in 'Colorado' and 'Mikado' cultivars is low compared with other apricot cultivars. Catechin, chlorogenic acid, neochlorogenic acid, epigallocatechin, and rutin have been reported as the major phenolics compounds in apricot, although their 
relative concentrations depend on cultivar and ripening stage $[2,33,35,36]$ In 'Colorado' and 'Mikado' apricots, three phenolic compounds were identified and quantified, the major one being chlorogenic acid followed by neochlorogenic acid and rutin (Table 4). It is worth noting that total or individual phenolic concentrations at harvest were not affected by preharvest melatonin treatment, although significant differences were observed during storage. Thus, total phenolic concentration in the control fruits of both cultivars increased during the first 7 days of storage at both temperatures and then decreased, except in the control 'Mikado' fruits stored at $8{ }^{\circ} \mathrm{C}$ in which a decrease occurred from day 0 (Figure 5) according to previous reports in the 'Shushanggan' cultivar [2]. However, in fruit from melatonin treated trees, the decrease of phenolic content was delayed in both cultivars and storage temperatures leading to higher phenolic levels in treated fruit from 14 to 21 and 28 days of storage (Figure 5). Given the antioxidant properties of phenolics and their reported health beneficial effects [30-32], melatonin treated apricots would maintain their health benefits after prolonged storage. Recently, it has been reported that dipping nectarine fruits for $30 \mathrm{~min}$ in $0.25,0.5$, and $1 \mathrm{mM}$ melatonin minimized phenolic losses during storage at $1{ }^{\circ} \mathrm{C} \mathrm{[14]} \mathrm{as} \mathrm{well} \mathrm{as} 0.1 \mathrm{mM}$ melatonin dipping for $10 \mathrm{~min}$ in peaches [13]. This high level of phenolic concentration has been related to enhancement of chilling tolerance in peaches, apart from the maintenance of a higher ratio of unsaturated to saturated fatty acids $[13,28]$. Thus, the reduction of CI observed in the present research in apricot fruits as a consequence of preharvest melatonin treatment (Table 3) could be due to the induced maintenance of higher phenolic concentrations (Figure 5). In addition, reduction on polyphenol oxidase (PPO) activity has been related to a lower $\mathrm{CI}$ incidence in apricot fruit [37] and, in turn, the higher phenolic content and the lower CI found in apricots from melatonin treated trees could be due to lower PPO enzyme activity. Accordingly, Koushesh Saba et al. [38] reported that postharvest melatonin treatment of pomegranate led to enhanced fruit chilling tolerance, which was related to inhibition of PPO activity. On the other hand, in other climacteric fruits, such as kiwifruit [39] and tomato [40], and even in non-climacteric fruits, such as pomegranate [41], a relationship between reduced ethylene production and lower chilling injury damage during cold storage has been observed. In this sense, the ethylene reduction described previously in this research could suggest that inhibiting ethylene biosynthesis with preharvest melatonin treatments could contribute to reducing chilling injury impact during apricot storage.

\section{Conclusions}

Results show that melatonin treatment of 'Colorado' and 'Mikado' apricot trees, at key points of fruit development, increased quality parameters at harvest, such as fruit weight and firmness, as well as crop yield. Chilling injury symptoms were reduced, and the evolution of parameters responsible for fruit quality reduction, such as weight, firmness, and acidity losses, were delayed in fruit from melatonin treated trees with respect to the controls at both storage temperatures, these effects being attributed to the reduced ethylene production found in treated fruits. Thus, melatonin could be a useful tool to improve apricot crop yield and maintain fruit quality properties during storage, as well as their content in bioactive compounds with health beneficial effects, such as phenolics.

Supplementary Materials: The following are available online at https:/ / www.mdpi.com/article/10 .3390/agronomy11050917/s1, Figure S1: Total soluble solid content of 'Colorado' (A) and 'Mikado' (B) apricots from control and melatonin treated trees during storage at 1 and $8{ }^{\circ} \mathrm{C}$. Data are the mean \pm SE of three replicates of ten fruits. LSD values were 0.018 and 0.019 for (A,B), respectively. Different capital and lowercase letters show significant differences $(t$-test, $p<0.05)$ between treatments for each sampling date during storage at 1 and $8{ }^{\circ} \mathrm{C}$, respectively. Figure S2: Total acidity content of 'Colorado' (A) and 'Mikado' (B) apricots from the control and melatonin treated trees during storage at 1 and $8{ }^{\circ} \mathrm{C}$. Data are the mean $\pm \mathrm{SE}$ of three replicates of ten fruits. LSD values were 0.006 and 0.005 for (A,B), respectively. Different capital and lowercase letters show significant differences ( $t$-test, $p<0.05)$ between treatments for each sampling date during storage at 1 and $8{ }^{\circ} \mathrm{C}$, respectively. 
Author Contributions: P.J.Z., M.S., D.V. and F.G. conceived and designed the work in association with other authors. J.M.-S., J.M.V. and F.G. performed the field treatments. J.M.-S. and F.G. performed most of the analytical determination in collaboration with J.M.V. Finally, M.S. and D.V. analyzed the data and wrote the manuscript. All authors have read and agreed to the published version of the manuscript.

Funding: This work has been funded by the Spanish Ministry of Science, Innovation, and Universities through Project RTI2018-099664-B-I00 and the European Commission with FEDER funds.

Institutional Review Board Statement: Not applicable.

Informed Consent Statement: Not applicable.

Data Availability Statement: Data are contained within the article.

Conflicts of Interest: The authors declare no conflict of interest. The funders had no role in the design of the study, collection, analyses or interpretation of data, in the writing of the manuscript, or in the decision to publish the results.

\section{References}

1. Martínez-Romero, D.; Serrano, M.; Carbonell, A.; Burgos, L.; Riquelme, F.; Valero, D. Effects of postharvest putrescine treatment on extending shelf life and reducing mechanical damage in apricot. J. Food Sci. 2002, 67, 1706-1712. [CrossRef]

2. Fan, X.; Xi, Y.; Zhao, H.; Liu, B.; Cao, J.; Jiang, W. Improving fresh apricot (Prunus armeniaca L.) quality and antioxidant capacity by storage at near freezing temperature. Sci. Hortic. 2018, 231, 1-10. [CrossRef]

3. Stanley, J.; Prakash, R.; Marshall, R.; Schröder, R. Effect of harvest maturity and cold storage on correlations between fruit properties during ripening of apricot (Prunus armeniaca). Postharvest Biol. Technol. 2013, 82, 39-50. [CrossRef]

4. Nourozi, F.; Sayyari, M. Enrichment of Aloe vera gel with basil seed mucilage preserve bioactive compounds and postharvest quality of apricot fruits. Sci. Hortic. 2020, 262, 109041. [CrossRef]

5. Pretel, M.T.; Serrano, M.; Amorós, A.; Romojaro, F. Ripening and ethylene biosynthesis in controlled atmosphere stored apricots. Eur. Food Res. Technol. 1999, 209, 130-134. [CrossRef]

6. $\quad$ Egea, I.; Flores, F.B.; Martínez-Madrid, M.C.; Romojaro, F.; Sánchez-Bel, P. 1-Methylcyclopropene affects the antioxidant system of apricots (Prunus armeniaca L. cv. Búlida) during storage at low temperature. J. Sci. Food Agric. 2010, 90, 549-555. [CrossRef] [PubMed]

7. Dubbels, R.; Reiter, R.J.; Klenke, E.; Goebel, A.; Schnakenberg, E.; Ehleers, C.; Schiwara, H.W.; Schloot, W. Melatonin in edible plants identified by radioimmunoassay and by high performance liquid chromatography-mass spectrometry. J. Pineal Res. 1995, 18, 28-31. [CrossRef]

8. Shi, H.; Chen, K.; Wei, Y.; He, C. Fundamental issues of melatonin-mediated stress signaling in plants. Front. Plant Sci. 2016, 7, 1124. [CrossRef]

9. Arnao, M.B.; Hernández-Ruiz, J. Is Phytomelatonin a New Plant Hormone? Agronomy 2020, 10, 95. [CrossRef]

10. Xu, T.; Chen, Y.; Kang, H. Melatonin is a potential target for improving post-harvest preservation of fruits and vegetables. Front. Plant Sci. 2019, 10, 1388. [CrossRef] [PubMed]

11. Liu, S.; Huang, H.; Huber, D.J.; Pan, Y.; Shi, X.; Zhang, Z. Delay of ripening and softening in ‘Guifei' mango fruit by postharvest application of melatonin. Postharvest Biol. Technol. 2020, 163, 111136. [CrossRef]

12. Hu, W.; Yang, H.; Tie, W.; Yan, Y.; Ding, Z.; Liu, Y.; Wu, C.; Wang, J.; Reiter, R.J.; Tan, D.X.; et al. Natural variation in banana varieties highlights the role of melatonin in postharvest ripening and quality. J. Agric. Food Chem. 2017, 65, 9987-9994. [CrossRef] [PubMed]

13. Gao, H.; Lu, Z.; Yang, Y.; Wang, D.; Yang, T.; Cao, M.; Cao, W. Melatonin treatment reduces chilling injury in peach fruit through its regulation of membrane fatty acid contents and phenolic metabolism. Food Chem. 2018, 245, 659-666. [CrossRef] [PubMed]

14. Bal, E. Effect of melatonin treatments on biochemical quality and postharvest life of nectarines. J. Food Meas. Charact. 2021, 15, 288-295. [CrossRef]

15. Tijero, V.; Muñoz, P.; Munné-Bosch, S. Melatonin as an inhibitor of sweet cherries ripening in orchard trees. Plant Physiol. Biochem. 2019, 140, 88-95. [CrossRef]

16. Liu, J.; Zhang, R.; Sun, Y.; Liu, Z.; Jin, W.; Sun, Y. The beneficial effects of exogenous melatonin on tomato fruit properties. Sci. Hortic. 2016, 207, 14-20. [CrossRef]

17. Abd El-Naby, S.K.M.A.; Mohamed, A.A.A.; El-Naggar, Y.I.M. Effect of melatonin, GA3 and NAA on vegetative growth, yield and quality of 'Canino' apricot fruits. Acta Sci. Pol. Hortorum Cultus 2019, 18, 167-174. [CrossRef]

18. García-Pastor, M.E.; Giménez, M.J.; Valverde, J.M.; Guillén, F.; Castillo, S.; Martínez-Romero, D.; Serrano, M.; Valero, D.; Zapata, P.J. Preharvest application of oxalic acid improved pomegranate fruit yield, quality, and bioactive compounds at harvest in a concentration-dependent manner. Agronomy 2020, 10, 1522. [CrossRef]

19. Debnath, B.; Hussain, M.; Li, M.; Lu, X.; Sun, Y.; Qiu, D. Exogenous melatonin improves fruit quality features, health promoting antioxidant compounds and yield traits in tomato fruits under acid rain stress. Molecules 2018, 23, 1868. [CrossRef] 
20. Ibrahim, M.F.M.; Abd Elbar, O.H.; Farag, R.; Hikal, M.; El-Kelish, A.; El-Yazied, A.A.; Alkahtani, J.; Abd El-Gawad, H.G. Melatonin counteracts drought induced oxidative damage and stimulates growth, productivity and fruit quality properties of tomato plants. Plants 2020, 9, 1276. [CrossRef]

21. Egea, M.I.; Sánchez-Bel, P.; Martínez-Madrid, M.C.; Flores, F.B.; Romojaro, F. The effect of beta ionization on the antioxidant potential of "Búlida" apricot and its relationship with quality. Postharvest Biol. Technol. 2007, 46, 63-70. [CrossRef]

22. Rastegar, S.; Khankahdani, H.H.; Rahimzadeh, M. Effects of melatonin treatment on the biochemical changes and antioxidant enzyme activity of mango fruit during storage. Sci. Hortic. 2020, 259, 108835. [CrossRef]

23. Fan, X.; Jiang, W.; Gong, H.; Yang, Y.; Zhang, A.; Liu, H.; Guo, F.; Cui, K. Cell wall polysaccharides degradation and ultrastructure modification of apricot during storage at a near freezing temperature. Food Chem. 2019, 300, 125194. [CrossRef] [PubMed]

24. Zhai, R.; Liu, J.; Liu, F.; Zhao, Y.; Liu, L.; Fang, C.; Wang, H.; Li, X.; Wang, Z.; Ma, F.; et al. Melatonin limited ethylene production, softening and reduced physiology disorder in pear (Pyrus communis L.) fruit during senescence. Postharvest Biol. Technol. 2018, 139, 38-46. [CrossRef]

25. Valero, D.; Serrano, M. Postharvest Biology and Technology for Preserving Fruit Quality; CRC Press: Boca Raton, FL, USA, 2010. [CrossRef]

26. Liu, J.; Yang, J.; Zhang, H.; Cong, L.; Zhai, R.; Yang, C.; Wang, Z.; Ma, F.; Xu, L. Melatonin inhibits ethylene synthesis via nitric oxide regulation to delay postharvest senescence in pears. J. Agric. Food Chem. 2019, 67, 2279-2288. [CrossRef]

27. Onik, J.C.; Wai, S.C.; Li, A.; Lin, Q.; Sun, Q.; Wang, Z.; Duan, Y. Melatonin treatment reduces ethylene production and maintains fruit quality in apple during postharvest storage. Food Chem. 2021, 337, 127753. [CrossRef]

28. Gao, H.; Zhang, Z.K.; Chai, H.K.; Cheng, N.; Yang, Y.; Wang, D.N.; Yang, T.; Cao, W. Melatonin treatment delays postharvest senescence and regulates reactive oxygen species metabolism in peach fruit. Postharvest Biol. Technol. 2016, 118, 103-110. [CrossRef]

29. Wang, F.; Zhang, X.; Yang, Q.; Zhao, Q. Exogenous melatonin delays postharvest fruit senescence and maintains the quality of sweet cherries. Food Chem. 2019, 301, 125311. [CrossRef]

30. Sureda, A.; Bibiloni, M.M.; Julibert, A.; Bouzas, C.; Argelich, E.; Llompart, I.; Pons, A.; Tur, J.A. Adherence to the Mediterranean diet and inflammatory markers. Nutrients 2018, 10, 62. [CrossRef] [PubMed]

31. Tarangon, E.; Moreno, J.J. Polyphenols and taste 2 receptors. Physiological, pathophysiological and pharmacological implications. Biochem. Pharmacol. 2020, 78, 114086. [CrossRef]

32. Luo, J.; Si, H.; Jia, Z.; Liu, D. Dietary anti-aging polyphenols and potential mechanisms. Antioxidants 2021, 10, 283. [CrossRef]

33. Ruiz, D.; Egea, J.; Gil, M.; Tomas-Barberan, F.A. Characterization and quantification of phenolic compounds in new apricot. (Prunus armeniaca L.) varieties. J. Agric. Food Chem. 2005, 53, 9544-9552. [CrossRef]

34. Drogoudi, P.D.; Vemmos, S.; Pantelidis, G.; Petri, E.; Tzoutzoukou, C.; Karayiannis, I. Physical characters and antioxidant, sugar and mineral nutrient contents in fruit from 29 apricot (Prunus armeniaca L.) cultivars and hybrids. J. Agric. Food Chem. 2008, 56, 10754-10760. [CrossRef] [PubMed]

35. Campbell, O.E.; Merwin, I.A.; Padilla-Zakour, O.I. Characterization and the effect of maturity at harvest on the phenolic and carotenoid content of northeast USA apricot (Prunus armeniaca) varieties. J. Agric. Food Chem. 2013, 61, 12700-12710. [CrossRef]

36. Kan, T.; Gundogdu, M.; Ercisli, S.; Muradoglu, F.; Celik, F.; Gecer, M.K.; Kodad, O.; Zia-Ul-Haq, M. Phenolic compounds and vitamins in wild and cultivated apricot (Prunus armeniaca L.) fruits grown in irrigated and dry farming conditions. Biol. Res. 2014, 47, 46. [CrossRef]

37. Koushesh Saba, M.; Arzani, K.; Barzegar, M. Postharvest polyamine application alleviates chilling injury and affects apricot storage ability. J. Agric. Food Chem. 2012, 60, 8947-8953. [CrossRef] [PubMed]

38. Jannatizadeh, A. Exogenous melatonin applying confers chilling tolerance in pomegranate fruit during cold storage. Sci. Hortic. 2019, 246, 544-549. [CrossRef]

39. Jiao, J.; Guo, L.; Liu, H.; Wang, Y.; He, Y.; Jin, M.; Rao, J. Effect of different packaging film thicknesses on chilling injury in postharvest 'Cuixiang' Kiwifruit. N. Z. J. Crop Hortic. Sci. 2020, in press. [CrossRef]

40. Yu, W.; Sheng, J.; Zhao, R.; Wang, Q.; Ma, P.; Shen, L. Ethylene biosynthesis is involved in regulating chilling tolerance and SlCBF1 gene expression in tomato fruit. Postharvest Biol. Technol. 2019, 149, 139-147. [CrossRef]

41. Kashash, Y.; Holland, D.; Porat, R. Molecular mechanisms involved in postharvest chilling tolerance of pomegranate fruit. J. Sci. Food Agric. 2019, 99, 5617-5623. [CrossRef] 